\title{
Investigating the sustainable fabric of the historical city of Marvast
}

\author{
M. Mangeli, M. Mangeli \& A. Sattaripour \\ Department of Architecture, Islamic Azad University, Iran
}

\begin{abstract}
Considering the importance of the conservation and restoration of historical places this study aims to investigate the general urbanism and the sustainable features of Marvast fabric in order to achieve a sustainable development procedure.

This case study was conducted as a field study by using previous studies, interviewing different people, taking photographs, collecting related information from the real place, and processing the collected information.

The whole fabric of Marvast was examined in terms of its sustainable development, the influential factors in its formation and its historical structure. Geomorphology, water resources and the way to access them, and continental elements are the factors that have influenced the formation of Marvast.

The only way for appropriate reconstruction of Marvast is the restoration of its sustainable economy along with repairing the residential and other culturally valuable buildings in a new form. Organizing Marvast fabric requires addressing its fabric-related problems with the minimum interventions. Continuing architectural studies and updating the designs based on the latest studies are also recommended.

Keywords: Marvast, sustainable desert architecture, urbanism, sustainable fabric, eco architecture, sustainable development, historic fabric, evolution path, skeletal knowledge.
\end{abstract}

\section{Introduction}

The historical city of Marvast is one of the oldest cities of Yazd Province in Iran and because of being located next to the Marvast Desert has desert architecture and urban design features. The central part of Marvast is established at the 
conjunction of the main connecting road with fertile lands and water resources (aqueducts).

Basically, in central part of Iran, the junction of main roads with aqueducts in flat and fertile plains has been the position of locating the initial central part of city. The land slope, the running track of aqueducts, geomorphologic conditions of the region, and ecological issues are considered to be the influential factors in formation of Marvast so that the further development of the city has been made in the direction of land slope and water run. Agricultural activities have been developing in this region from the ancient times, therefore the city is considered as one of the agricultural and population centers of Iran. This plain is now where Marvast City is located. This city like other small desert cities of Iran is not adequately recognized and studied. The only studies conducted about the city and its structure are basic studies conducted by Consulting Engineers Group of Iranian Dwelling Association to prepare the city plan [1].

This paper aims to study the formation features of the central part of the city, its evolution procedure in different periods, and also its fabric based on field and library studies.

\section{Methods and materials}

This study was conducted based on the existing data as a historical research focusing on the small desert city of Marvast in Yazd Province. The goal of this study is to determine the sustainable historical fabric status of the city, its evolution procedure, and the factors that influence them.

The historical fabric of the city was selected as the subject of the study and we attempted to consider some main urban factors and their effects on formation of the city in order to provide a useful resource for future repair works and reconstruction of the city.

Marvast is located 185 kilometers south of Yazd Province Center in YazdHarat Road. The city is located at $54^{\circ} 10^{\prime}$ to $54^{\circ} 13^{\prime}$ ' east longitudes and $30^{\circ} 27^{\prime}$ to $30^{\circ} 29^{\prime}$ north latitude with an average height of $1538 \mathrm{~m}$ and an area of $4 \mathrm{~km} 2$ in the plain region [2].

The dominant ecological regions of this territory can be divided into three following categories:

1- Desert ecological region

2-Semi-desert ecological region

3 - Moderate ecological region with average rainfall of $85.5 \mathrm{~mm}$.

Marvast is located at a plain region covered with Neogene sediments. It is faced with high risk of earthquake regarding earthquake relative risk gradation. Marvast is the smallest city of Yazd with a 250-Hectare area and a population of 6934 (male: 3492, female: 3442) according to 1994 statistics. There are 1777 families in Marvast and the population relative density is 34 people per square kilometer. 

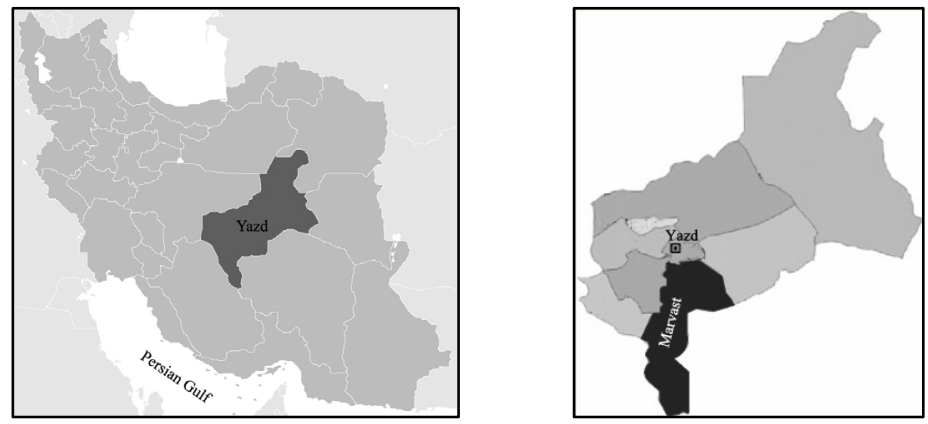

Figure 1: The position map of Yazd province and Marvast city.

According to the classification of practitioners based on the main activities in $1994,37.63 \%$ out of 2668 practitioners who are more than 10 years work in agriculture, $42.62 \%$ work in industry, and $19.15 \%$ work in services sectors and others work in other main activities [3].

Harat and Marvast are two famous villages near Shahrbabak and are considered as two very old villages of the city. It is assumed that Aryans after immigrating to Iran used their previous villages' names to call the new ones, therefore Harat was named in memory of the famous village of Harat and Marvast was named in memory of Marv village [4].

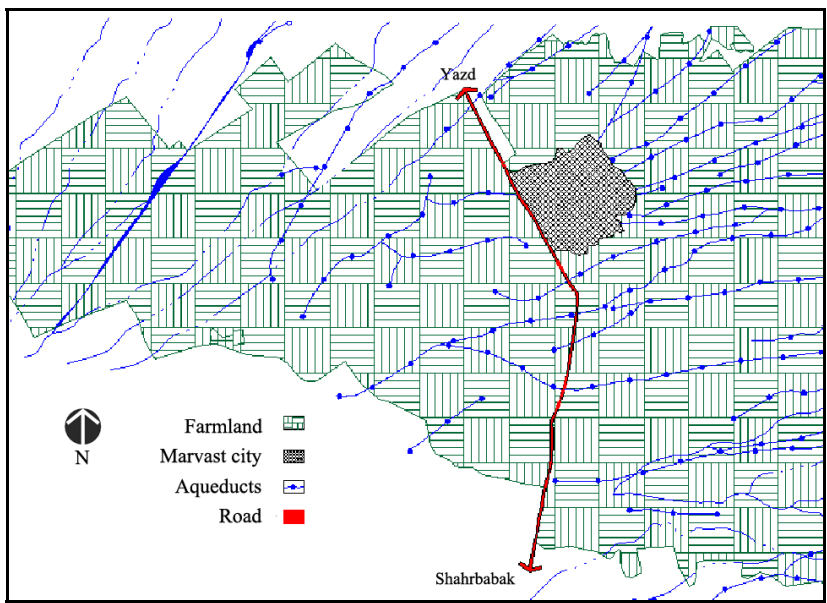

Figure 2: $\quad$ Formation position of Marvast influenced by different factors. 


\section{Discussion}

\subsection{Formation of Marvast}

The central part of Marvast is established at the junction of the main connecting road with fertile lands and water resources (aqueducts). The land slope, the running track of aqueducts, geomorphologic conditions of the region, and ecological issues are considered to be the influential factors in formation of Marvast so that the further development of the has been made in the direction of land slope and water run.

The land slope, the movement run of city 's aqueducts also geomorphologic conditions have considered as effective factors on Marvast formation also further development of city, in which further development of city was done based on land slope and water run.

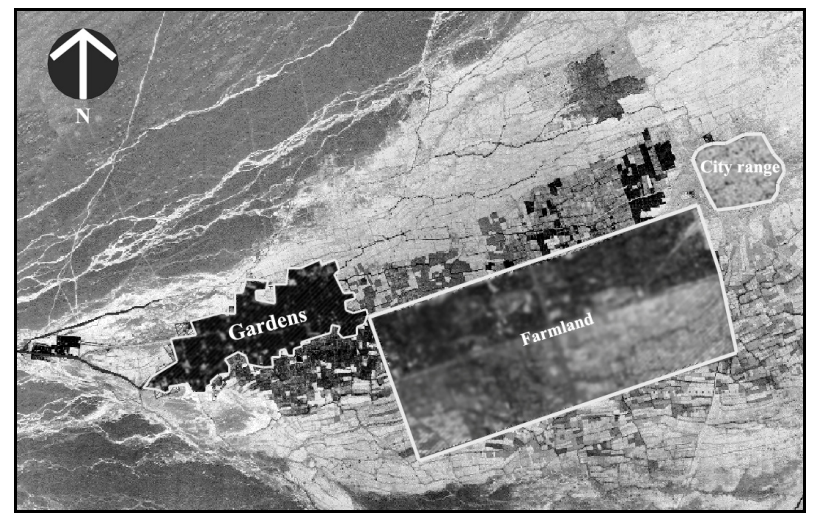

Figure 3: Establishing position of farm lands and gardens were determiner factors for forming city and its development in next periods.

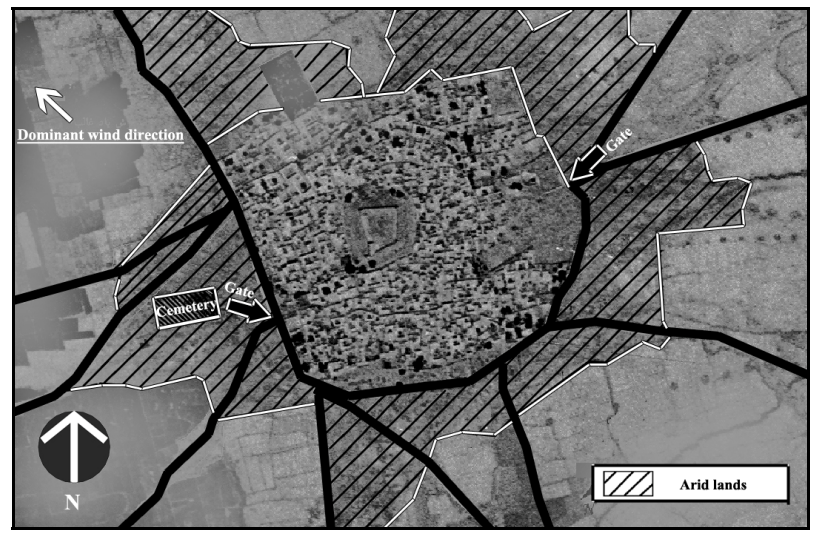

Figure 4: Circle of barren land ringed the city and cemetery position in land. 


\subsection{The old urbanization structure of Marvast}

Marvast is formed near the old road connecting Harat to Mehriz and Yazd in a fertile plain with many aqueducts.

Based on an aerial image in 1995, we can conclude that the old Marvast at first has had a circular pattern and its residential sections have been formed around a castle then it was further developed into the lands around the old city with ramparts and towers built to provide security. Now there are no traces of the old city and the ramparts of the new one. The only remainder of this old coordinated urban system is one of the towers of the secondary fence of the city.

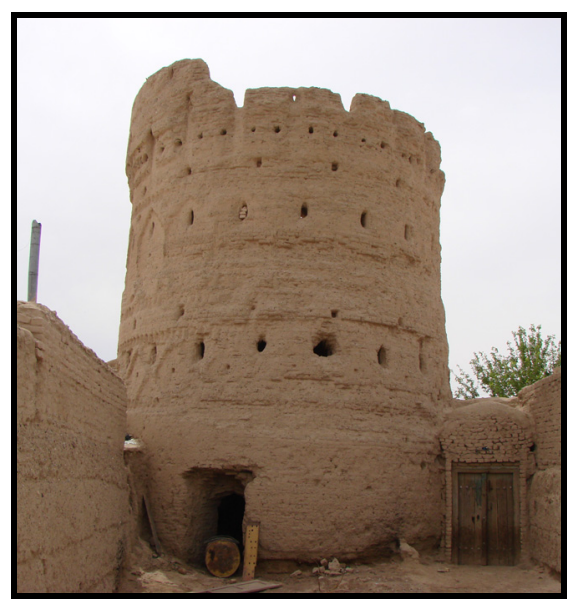

Figure 5: The only remaining signs of Marvast city productivity.

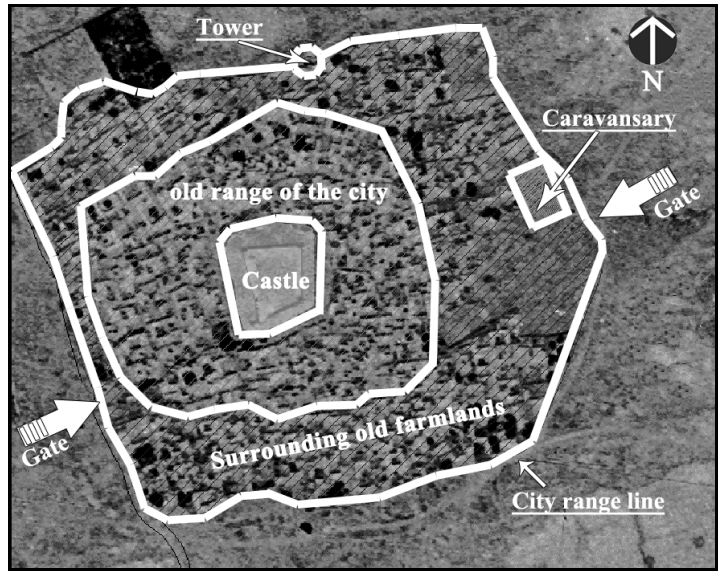

Figure 6: The Old Marvast City and further development on surrounding lands. 
The general perspective of the structure of the city includes a city surrounded with fence and rampart and two gates one opened into Harat-Mehriz road and the other, Ghasem Abad Gate, used as an entrance for caravans and passengers coming from the neighbor villages. Two caravansaries were established next to the gates [5].

The old Marvast has had a complete structure and skeleton consisted of three following main parts:

- Castle

- Middle flux including residential sections and services sections such as Bazaar and Jaame' mosque, and

- Outward or Rabaz that due to further development of the city and population growth became residential and fences were built to provide security.

The skeleton of the pathways of the old fabric in the residential circle around the castle is in a radial form for providing quick access to the castle upon a danger. This formation pattern of the pathways indicates their antiquity and the priority of the establishment of the residential circle in relation to other parts of the fabric. Further development of the city followed a checkered pattern in accordance with the agricultural land divisions that shows the formation of the city in surrounding lands. Beside these two structural patterns, there are circular pathways that seem are established on the walls of the old city. According to above mentioned information, Marvast historical fabric consists of the following distinct parts:

1- Marvast Castle: this castle was the central part of the city located at the geometric center of the city and was used during the enemies' attacks (fig. 7).

2- The fabric around the castle: a collection of brick and clay houses all with an internal yard that like all of the old building at the margins of desert cities have an extrovert view. These houses are connected to the central part of the city through narrow and organically formed meandering pathways. The main buildings of the city such as Jaame' mosque, reservoir, bath, and bazaar are established in this part of the city around the castle providing the most convenient access for the dwellers.

3- The fabric around the old wall of the city: this part of the city is the second developmental circle of the city and encompassed some of the agricultural lands of the old city. The establishment of buildings and pathways in this part follows the segmentation pattern of agricultural lands. The brick and clay houses are organized serially and the pathway network follows the farming lands boundaries pattern, therefore this part of the city has a checkered pattern. These pathways have a relatively fixed width without any meander. The houses in this part are made of brick and clay and have a central yard but their view is different from that of the houses established around the castle and compared to the fabric around the castle has a rural view with no valuable buildings. The walls are short and the gates are simple without any portal. 


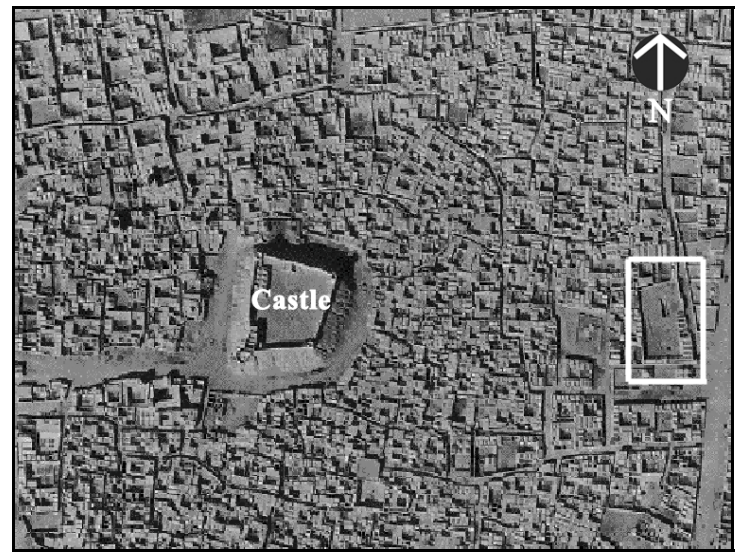

Figure 7: Ghasem Abad Caravansary and its position regarding the castle.

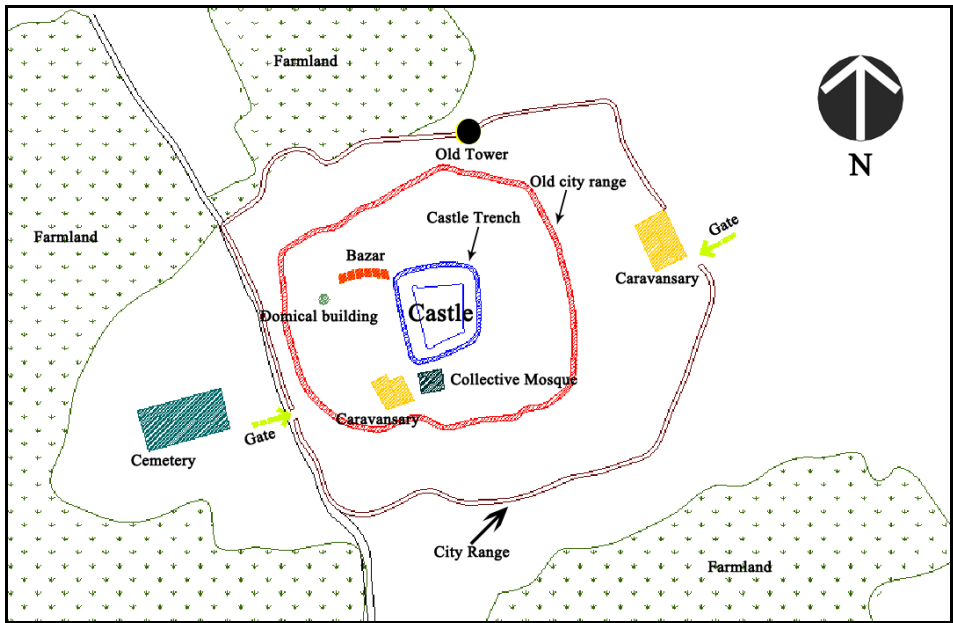

Figure 8: $\quad$ The old structure of Marvast and its main elements.

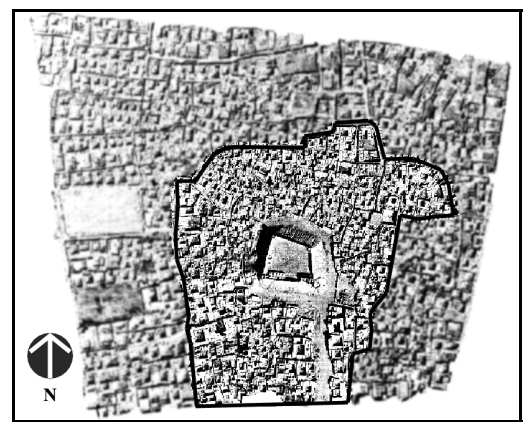

Figure 9: The fabric included around castle. 


\subsection{Fabric framework}

The framework of the historical fabric of Marvast has the skeleton of the plaindesert villages that is established around a castle named "Nafs-ol-Gharye". In present situation seven regions including Khajeha, Falahatiha, Arjmandiha, Hosseinieh, Shah Hossini, Haj Ghasem, and Dehghaniha surround the central part of the city as a residential circle with narrow and meandering alleys [6]. Further development of the city has been occurred in an area of about 25 hectares in the last century.

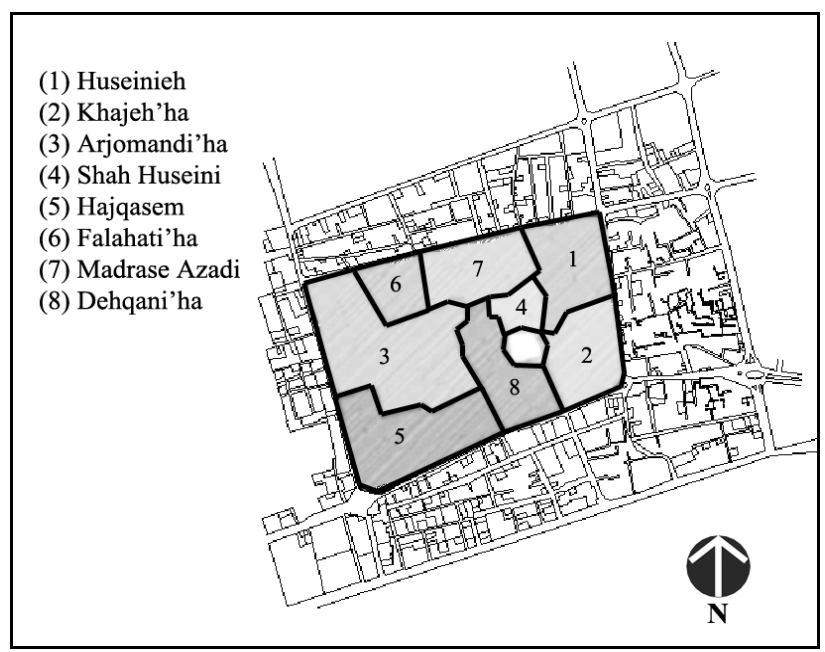

Figure 10: The present status of historical fabric districts of Marvast.

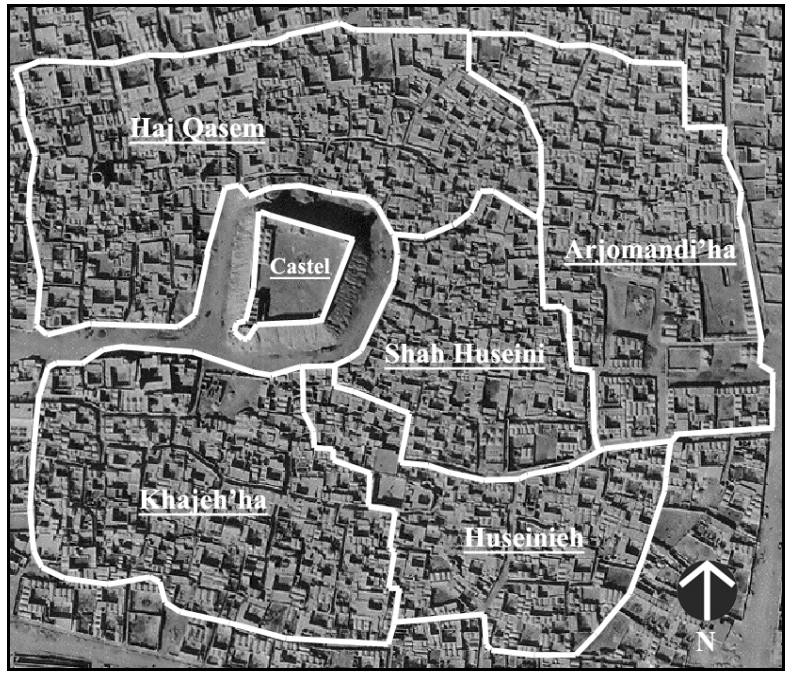

Figure 11: The former districts around Marvast Castle. 


\subsection{The central part of city}

Nafs-ol-Gharye Castle is located on a hill at the center of the city and constitutes the central part of the city. The exact age of the castle is unknown. The castle has a square shape with long crenellated walls and three round towers each in one corner of the castle. In the southwest corner we can see the portal of the castle gate. The gate leads to a porch with a domical ceiling.

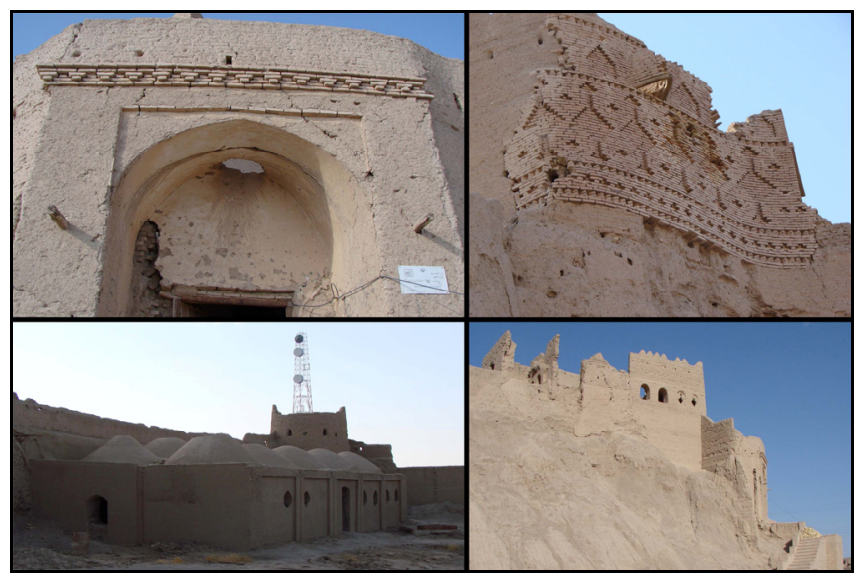

Figure 12: The four surfaces of outside and inside space of Marvast Castle.

The castle is constructed on a hill. The soil of the hill is believed to be handmade. There has been a moat around the castle before the beginning of the present century. The location of the castle is such that it overlooks the whole Marvast plain.

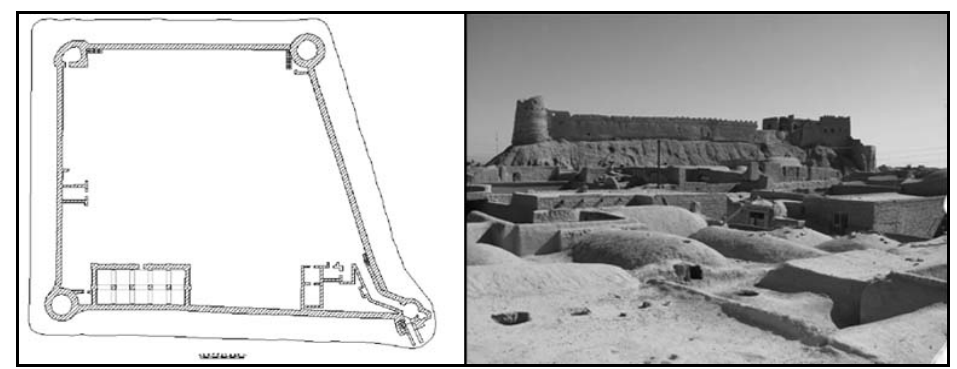

Figure 13: The plan of Nafsol Ghariye Castle and its constructed position as a border and its defending dam.

\subsection{The old bazaar}

The bazaar complex leads to the area around the castle and is in close relation to the central part of the old city. Bazaar is composed of covered passages 
(penthouses) with the shops in both sides. It is covered with arch and Toveize and each arch has a skylight. There were a reservoir and old bath in bazaar.

The old fabric of Marvast has a hierarchical accessibility system for providing convenient access from extra regional to intraregional and dead end locations. The existing pathways around the castle are divided into four groups: first grade pathways (main pathways), second grade pathways (extra regional pathways), third grade pathways (intraregional pathways), and fourth grade pathways (private pathways).

\section{The characteristics of landscape in the districts of Marvast historical fabric}

\subsection{Symmetry and composition}

Symmetry is a very important feature for the sustainable use of spaces, construction materials, and solar and wind energy. One of the characteristics that is observed in the buildings remained in Marvast old fabric is the existence of symmetry.

The most important visual impact of the symmetry is balance and appropriate coordination and composition. When the structural collections are composed together and provide an enclosed space the need for coordination in terms of uniformity appears so a collection of different buildings with different applications can come to existence as a coordinated unit in the form of so-called "fabric". This enclosure and the coordination of construction materials are very influential in saving solar energy and preventing waste of internal energy.

We cannot see any straight passage with a fixed width in the old districts of Marvast. The different width of the passages, recess of the houses, meandering alleys, arches and penthouses, open spaces of Hosseinieh, the entrance space of Shah Hossein Mosque, and the spatial hierarchy for accessibility all together provide a spatial paradox (fig. 14).

The connecting spaces such as main roads and semi-square spaces that connect different elements of the city to city center have dynamic and static characteristics. It means that spaces such as squares and crossroads are static but

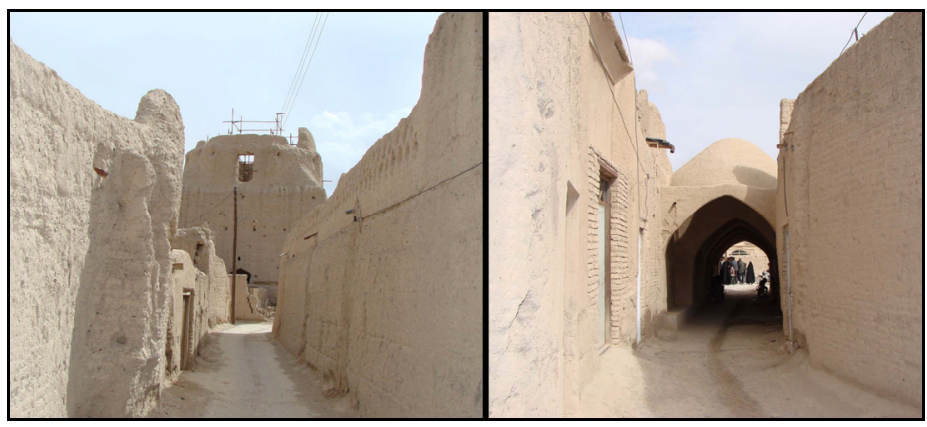

Figure 14: Restriction in internal pathway in bazaar. 
passages and streets are dynamic. In contrast to a semi-square space which is static, a rectangular space has dynamicity in its length (figs. 14 and 18).

Enclosing the spaces is known to be the primary dominant principle in designing sustainable urban places so that an attractive urban place cannot be established unless it is properly enclosed. This principle is universal in most of old cities all over the world and the old fabric of Marvast also follows it (fig.14).

In old fabric of Marvast where less interventions have been made we can see a complete coordination among the shape and the dimension of elements and color, fabric, and type of construction materials. Also the arches, domes, and false roofs and their regular repetition provided the fabric with coordination, but this coordination is being destroyed due to the destructions and inappropriate renovations. Some non-coordinated constructs and heterogeneous construction materials have damaged the attractive face of the city (fig. 15). The coordination of color and fabric is another factor that provides the possibility of exploiting solar energy in winter and shadow of the constructs in summer.

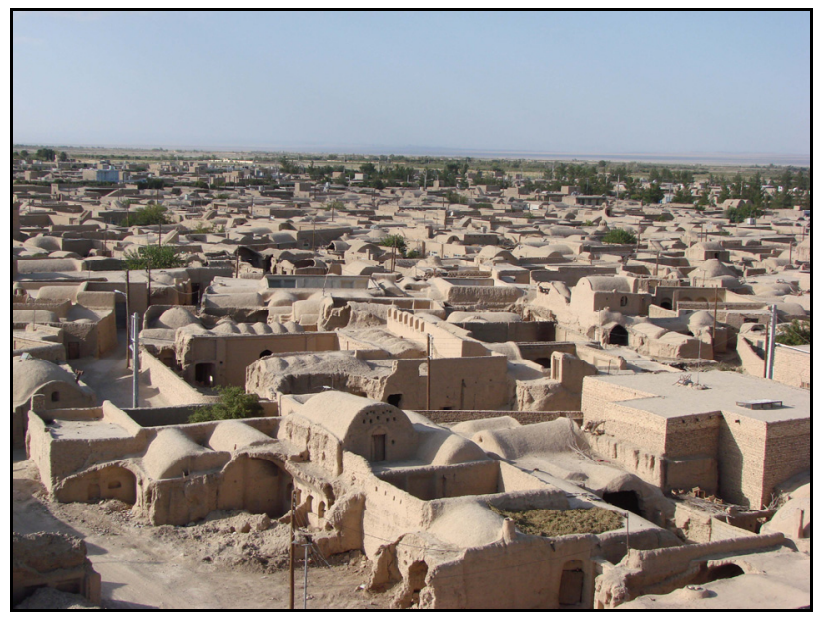

Figure 15: General surface of historical fabric of Marvast.

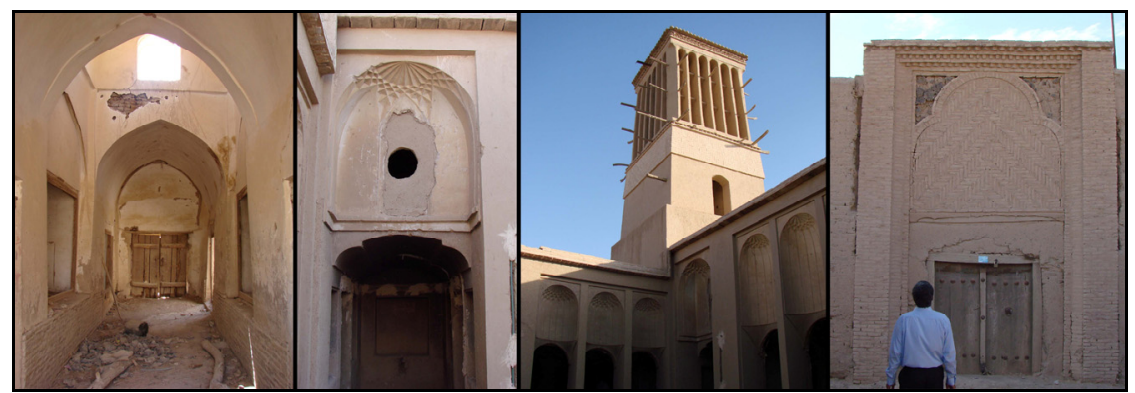

Figure 16: The Vaghfi house with entrance decorative porch and its Windcatcher. 


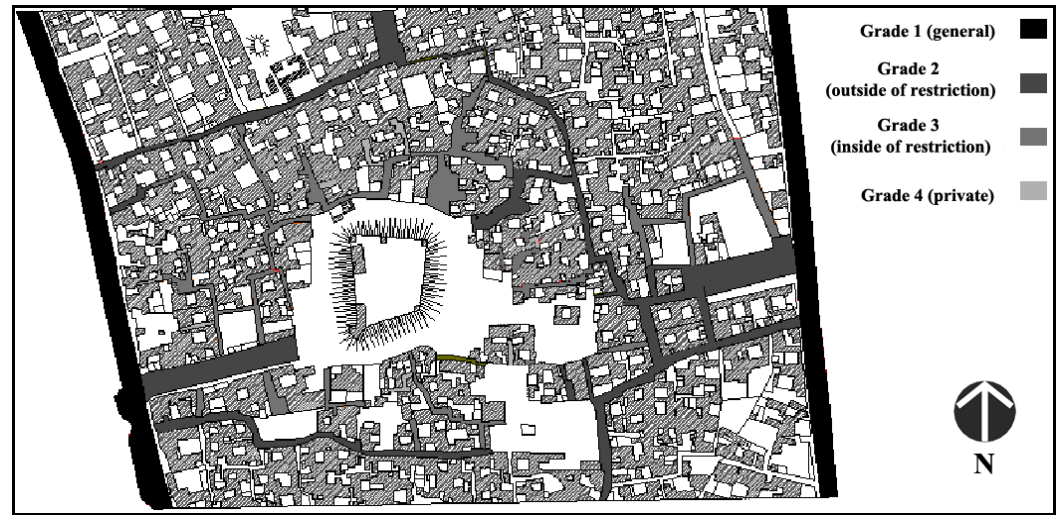

Figure 17: The degrading of roads in historical fabric of Marvast.

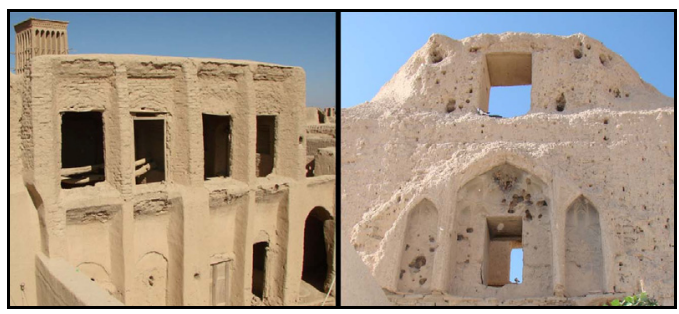

Figure 18: The available symmetric picture outside surface of domical building and symmetric picture of old house.

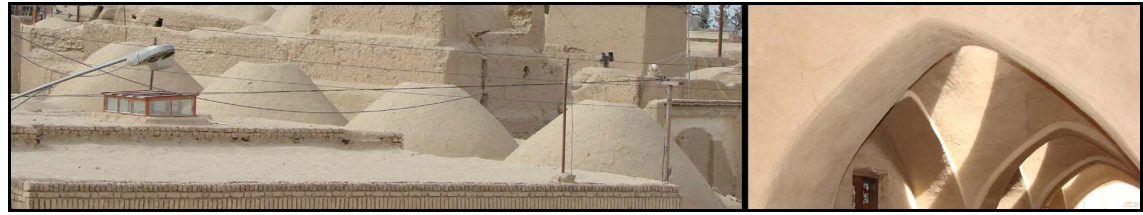

Figure 19: Repeated domes as sustainable element for urban space.

The houses' high wind catchers, the long walls of dome-shaped buildings, and the castle established on the hill are the elements helpful in finding directions that is another visual feature embedded in Marvast old fabric [7].

We face completely distinct spaces within the districts. The main pathway, the open area of the district center, and Hosseiniehs are public, alleys are semipublic-semiprivate, and dead end alleys and porches that lead to private areas of residential units are semiprivate-semipublic areas. 


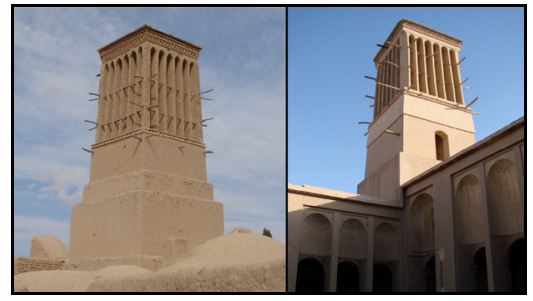

Figure 20: Windcatcher helps to ventilate and make proper air flow inside houses.

\section{Conclusion}

The climate, the structure and shape of the land might be the most important factors in the formation of Marvast. Different factors such as geomorphology, water resources and the ways to access them, and continental elements are the factors that have influenced the formation of Marvast. The agriculture-based economical system of the city is the reason of its being surrounded by a circle of urban lands that caused a circle-like shape for the city. The districts of the city and their internal connecting structures follow an organic pattern so that they are arranged around a nucleus in a radial form. The only way for appropriate reconstruction of Marvast is the restoration of its sustainable economy along with repairing the residential and other culturally valuable buildings in a new form. Organizing Marvast fabric requires addressing its fabric-related problems with the minimum interventions. Continuing architectural studies and updating the designs based on the latest studies are also recommended. This fabric contains valuable buildings that their repairing and protecting is dependent on the protection of the fabric around them.

\section{References}

[1] ShabestanYazd Consulting Engineers, Urban Design of Marvast City, 2004.

[2] Geography Organization of Ministry of Defense, Geographical Culture of Villages of Yazd province, 2nd edition, pp. 137-447, 2002.

[3] Management and Planning organization, Social-Economic report of Yazd Province, 2002.

[4] Bastani Parizi, M., Peyghambar Dozdan, Negah Publications, Tehran, 1985.

[5] Afshar, I., Memories of Yazd, Publications of Cultural Works, 2nd edition, Tehran, p. 323, 1995.

[6] Hosseini Musa, Z., Shahrbabak, The Turquoise Land, Publications Center for Kerman Recognition, p. 134, 2003.

[7] Mangeli, Ma., Reconstruction of Marvast Domical Building (Chapter of historical studies), Thesis of Master's Degree Course, Islamic Azad University, Tehran Central Branch, 2007. 